\title{
Are the Supporters of Populist Parties Loyal Voters? Dissatisfaction and Stable Voting for Populist Parties
}

\author{
Remko Voogd ${ }^{1 *}$ and Ruth Dassonneville ${ }^{2}$ \\ ${ }^{1}$ Remko Voogd, Faculty of Social and Behavioural Sciences, University of Amsterdam, the Netherlands, \\ and ${ }^{2}$ Ruth Dassonneville, Department of Political Science, University of Montreal, Canada \\ ${ }^{*}$ Corresponding author. Email: R.J.Voogd@uva.nl
}

(Received 14 December 2017; revised 12 June 2018; accepted 26 June 2018; first published online 17 September 2018)

\begin{abstract}
Scholars of electoral behaviour regularly link political dissatisfaction to two types of behaviour: voting for populist parties and unstable voting behaviour. It is therefore not surprising that the electorates of populist parties are generally assumed to be rather volatile. In this article, we argue that this is not necessarily the case - in particular in a context of increasingly strong and viable populist parties. We make use of data from the Comparative Study of Electoral Systems project to show that voters for populist parties are neither more nor less volatile than voters for mainstream parties. Political dissatisfaction among voters for populist parties even increases the likelihood of stable voting for populist parties. The supply of populist parties further conditions the stability of the populist vote, as voters in systems with established populist parties are more likely to vote stably for populist parties. Finally, we find that in a context of strong and stable populist parties, the effect of political satisfaction on vote switching is somewhat reduced.
\end{abstract}

Keywords: populist vote; electoral volatility; dissatisfaction; supply side; CSES data

In this article we assess how the stability of voting patterns over the course of two consecutive elections is affected by political dissatisfaction and populist party voting and whether the effects of the former are conditional upon the latter. First, as voting patterns have become increasingly volatile (Chiaramonte and Emanuele 2017; Dassonneville and Hooghe 2017a), it is often argued that the tendency to switch one's vote stems from an alleged 'crisis in political support'. Several individual-level studies convincingly show that political dissatisfaction is correlated with unstable voting behaviour (e.g. Dalton and Weldon 2005; Dejaeghere and Dassonneville 2017; Söderlund 2008). Second, the alleged crisis in political support has also been linked to the rise of populist parties (Van Kessel 2015; Mudde 2013). Those expectations are also backed up by a large literature showing individual-level evidence of a relation between political dissatisfaction and voting for populist 
parties (e.g. Arzheimer 2009; Dalton and Weldon 2005; Lubbers et al. 2002; Pauwels 2014; Werts et al. 2013).

Considering these literatures together, political dissatisfaction has been linked with two types of behaviour; the politically dissatisfied are expected to change their votes regularly and they are expected to be more likely to vote for populist parties. Those expectations might have been simultaneously true in the 1980s and 1990s, when electoral support for populist parties was strongly fluctuating in most Western democracies (Nedelcu 2015). However, the electoral support for populist parties increased strongly in several long-standing Western democracies from the 2000s onwards (e.g. Hartleb 2015; Van Kessel 2015). As a result, the thesis that dissatisfied voters in general - and more particularly the dissatisfied voters of populist parties - are regular vote-switchers may no longer hold in political systems where dissatisfied voters can vote stably for viable populist party alternatives. In other words, the rise of populism necessitates that we revisit the relation between political dissatisfaction and vote switching.

The argument that we pursue in this article is that the stability of the vote of dissatisfied voters is conditional upon the type of party they previously supported: a populist party or a mainstream party. Because the rise of populist parties seems hardly explainable without such parties having attracted a larger core base of supporters, we argue that dissatisfied voters who switched their votes to populist parties may very well become rather stable voters again. In addition, we argue that politically dissatisfied citizens are more likely to develop attachments to populist parties in systems in which populist parties have already effectively established themselves in parliament.

In order to assess whether populist party support indeed conditions stable and volatile voting among politically dissatisfied citizens, this article first assesses whether voters for populist parties are more or less volatile than the electorate of mainstream parties. Secondly, we examine whether political dissatisfaction stabilizes voting behaviour among populist party voters. Thirdly, we look at how the viability and the effective presence of populist parties in parliament conditions the extent to which their voters are stable or volatile voters.

To investigate these research questions, we present an individual-level analysis of the stability of voting for (populist) parties in established democracies. ${ }^{1}$ We make use of the data from modules 2, 3 and 4 of the Comparative Study of Electoral Systems (CSES) project, covering a wide range of 32 elections from 2001 to 2016 in 14 Western democracies. This data set makes possible an investigation of the stability of (populist) party choices, as well as the effects of political dissatisfaction on stable or volatile voting. We analyse these data by means of multilevel modelling.

\section{How do the dissatisfied vote?}

In democratic systems, citizens who are - temporarily - dissatisfied with specific authorities can punish officeholders by not voting for them. Those who previously supported the incumbent party, for example, can switch their support towards other (opposition) parties (Dalton and Weldon 2005: 941; Zelle 1995). Vote switching as a result of short-term dissatisfaction with the performances of specific officeholders particularly government (or parties) - applies to voters of all parties alike and can 
positively be understood as an indication that voters are performing their democratic task of critically evaluating officeholders (Van der Meer et al. 2015; Norris 1999).

In addition, a more deep-seated attitude of political dissatisfaction towards political institutions and mainstream political actors in general is likely to affect voting behaviour and the stability of the vote as well. ${ }^{2}$ Citizens who are structurally dissatisfied with the way democracy works can use their vote to continually reject incumbents regardless of who holds power (Dalton and Weldon 2005; Zelle 1995). A fairly stable and general sense of political dissatisfaction is thought to make voters critical of every aspect of the political system (Söderlund 2008: 222), which hinders the development of emotional bonding with specific parties and encourages a willingness to respond to short-term electoral factors (Dalton 2004). As a result, distrusters lack incentives to form stable party preferences, leading them to support new contender parties more often (e.g. Bélanger and Nadeau 2005: 127; Dalton and Weldon 2005: 940). Multiple studies have shown that political dissatisfaction is indeed related to higher levels of vote switching (e.g. Dalton and Weldon 2005; Dejaeghere and Dassonneville 2017; Söderlund 2008).

A second body of literature studying the behaviour of generally dissatisfied citizens argues that they are more likely to vote for populist parties. Populists basically separate society into two homogeneous and antagonistic groups: 'the pure people' versus 'the corrupt elites' and argue that the former should reclaim popular sovereignty to prevent the corrupt elites from continually betraying them (e.g. Van Kessel 2015; Mudde 2004; Rovira Kaltwasser 2012). Anti-elitism is thus one of the core elements of populism (Rooduijn 2018), and this anti-elitism is directed towards all mainstream political officeholders (including mainstream opposition parties). As such, anti-elitism is often measured by means of indicators of 'generalized political dissatisfaction' or 'political disaffection' (Rooduijn et al. 2016). While generalized dissatisfaction clearly originates from dissatisfaction with specific policies and institutions (Zelle 1995), it goes beyond specific distrust. In fact, focusing only on the latter would not allow a distinction to be made between citizens who are dissatisfied with mainstream politics in general and citizens who are only temporarily dissatisfied with the policies implemented by temporarily disliked officeholders (e.g. mainstream opposition supporters).

As dissatisfied voters and populist parties share a fierce criticism of the establishment (Bergh 2004), voting for populist parties may well appear as the most attractive electoral option for dissatisfied voters (Bélanger and Nadeau 2005; Van der Brug et al. 2000), in particular when populist parties succeed in presenting themselves as political outsiders (Bélanger and Aarts 2006; Rooduijn et al. 2016: 34). ${ }^{3}$ The existence of an individual-level relationship between generalized political dissatisfaction and voting for populist parties has been demonstrated in specific countries (Mayer and Perrineau 1992 (France); Swyngedouw 2001 (Belgium); Schumacher and Rooduijn 2013 (the Netherlands); Lubbers and Scheepers 2000 (Germany)), and in cross-national comparative studies (Arzheimer 2009; Betz 1994; Dalton and Weldon 2005; Lubbers et al. 2002; Norris 2005; Pauwels 2014; Werts et al. 2013). ${ }^{4}$

\section{The stability of the populist vote: theory and expectations}

Previous work has linked dissatisfaction with both instability in the vote and with voting for populist parties. It is therefore not surprising that the populist vote has 
generally been expected to be rather volatile (Arzheimer 2009: 259; Van der Brug et al. 2005). There are in fact good theoretical reasons for expecting instability in the electorate of populist parties. First, the attractiveness of populist leaders which helps to attract votes - tends to dissipate over time (Schumacher and Rooduijn 2013: 126). Second, when a populist party becomes electorally successful and establishes parliamentary representation, it has more difficulty presenting itself as an 'anti-elitist' movement (Schumacher and Rooduijn 2013: 126). Finally, Anthony Downs' (1972) issue-attention cycle theory states that voters will not focus on a single issue for a long period of time. At some point in time, hence, populist parties' focus on anti-elitisms no longer attracts voters' attention (Poznyak et al. 2011: 675).

Empirical studies of (in)stability in voting for present-day populist parties are scarce. However, some empirical contributions relying on data from the 1990s have shown that even though populist parties temporarily benefited from dissatisfied voters, their support was rather unstable (Bergh 2004). In a study of the electorate of the populist French National Front in the 1990s, for example, the majority of those voters were described as 'protest voters that come and go' without really identifying with the party (Mayer and Perrineau 1992: 123). Such findings suggest regular switching between populist and mainstream (opposition) parties.

This rather scattered evidence from the 1990s has strengthened the assumption that voters who vote for populist parties are unstable. We argue that this assumption should be reassessed because of the rise in electoral support for populist parties in several advanced democracies. The continued presence of populist parties in many national parliaments (Van Kessel 2015: 187; Mudde 2013) suggests that present-day populist parties might now have a core group of loyal voters. Of course, growing support for such parties implies that populists still attract new voters - who necessarily make a switch from a mainstream party (or from abstention). But the fact that populist support has continued to grow over a series of elections in several countries - or has stabilized at a high level - suggests that populist parties have built an electoral base of core voters.

The emergence of an increasingly stable populist electorate would also fit with the insights on the emergence of a new cleavage in established democracies. Several authors argue that a 'transnational cleavage' has emerged that has the capacity to (re)structure the voting behaviour of the 'losers of globalization' (Hooghe and Marks 2018; Kriesi et al. 2006, 2008). This cleavage mainly constitutes a conflict between the 'winners' of globalization (the middle classes who profit from open borders, European integration and international economic competition) and the 'losers', who are dissatisfied with the unquestioned support of the current elites for this ongoing process (Hooghe and Marks 2018). As this new dimension crosscuts the traditional structural and political cleavages on which mainstream political parties continued to compete, the party system is more likely to respond to this structural change in voter preferences by means of the growth of new political parties instead of an incremental change in the established parties. Hence, with the winner/loser of globalization cleavage becoming more and more salient since the euro- and migration crises (Hooghe and Marks 2018), new opportunities emerge for challenging (populist) parties to position themselves exclusively on the new divide as the opponents of the current elites (left- and right-wing populist parties) 
and the defenders of the sovereign nation state and national identity (mostly rightwing populist parties). The increased saliency of this divide subsequently provides populist parties with an improved structural basis to attract loyal support (Hooghe and Marks 2018; Van Kessel 2015; Kriesi et al. 2008; de Vries and Hobolt 2012).

In other words, it is very well possible that the electorates of populist parties are more stable now than they were before. Focusing on a period in which populist parties in several countries are electorally successful, we do not expect voters for populist parties to be particularly volatile.

Hypothesis 1: Voters for populist parties are not more likely to switch their votes than voters for mainstream parties (party switching and switching to abstention).

Even if those who vote for populist parties are not more volatile than those who choose mainstream parties, as we hypothesize (Hypothesis 1), it does not yet explain whether it is indeed political dissatisfaction that binds voters to populist parties.

Dissatisfaction with the political establishment is one of the most important individual-level attitudes on which populism thrives. However, because dissatisfaction is also correlated with vote switching, it is questionable whether generalized dissatisfaction with politics is compatible with loyally supporting a party, even if it is a populist one. In this regard, it should be noted that several scholars now argue that stable party support and generalized dissatisfaction with politics are not mutually exclusive. That is, those who are dissatisfied with politics in general are not necessarily unhappy with their own parties or representatives (e.g. Norris 2011; Söderlund 2008). We therefore argue that - besides attracting voters to populist parties - political dissatisfaction will also influence how dedicated and loyal the supporters of populist parties are (and thus discriminate between occasional and loyal populist party voters).

Thinking of dissatisfaction as a stabilizing factor of populist party support takes into account that not all populist party voters are strongly dissatisfied with politics. Some voters support populist parties because of specific policy issues (e.g. Van der Brug et al. 2000; Rooduijn 2018). ${ }^{5}$ For them, dissatisfaction with politics might not be as strong as among the prototypical populist party voter. Issue-based populist party voters can choose from a broader set of appealing party options when deciding for whom to vote, as they can vote for mainstream contenders who advocate (less radical versions of) the same policies (Van der Brug et al. 2005). In contrast, the voting alternatives for those who are dissatisfied with the current establishment are more limited (to only true anti-establishment parties).

Turning to demand-side explanations for populist party support, dissatisfaction is found to be related to loyal populist party support (Schumacher and Rooduijn 2013). Recent findings also show that strong populist attitudes encourage voters to vote for populist parties. ${ }^{6}$ In fact, populist attitudes (and distrust) are the sole determinants unifying the supporters of both populist radical left and populist radical right parties (Akkerman et al. 2017). Those attitudes may even serve as a 'motivational substitute' when citizens' policy preferences are (partly) incongruent with the agendas of populist parties (Van Hauwaert and Van Kessel 2018). Finally, voters who support populist parties because they are politically dissatisfied might 
become even more dissatisfied as populist parties further fuel the discontent of their supporters (e.g. Bartels 2002; Van der Brug 2003; Rooduijn et al. 2016). For all these reasons, we expect that the most dissatisfied will also be the most loyal populist party voters:

Hypothesis 2: Political dissatisfaction increases the likelihood of a stable party vote among voters for populist parties.

The supply and effectiveness of populist parties in a political system are evident contextual factors that may help to activate the transition from populist attitudes at the individual level into actual (stable) electoral support for populist parties. Voters have to be continually exposed to a party's message to continue voting for them (Vliegenthart et al. 2012), which means that populist parties who already obtained substantial representation in parliament have a comparative advantage over more marginal populist parties. For populist parties that are only marginally (or not) represented in parliament, it might be more difficult to generate continuous visibility in the public debate. Strategic considerations may further stimulate vote switching among supporters of marginal populist parties, as voters could conclude that their party is not effective in influencing policies (Bos and Van der Brug 2010), let alone in governing (Blais et al. 2006; Rosema 2006). For pragmatic reasons, such voters could switch to a larger (mainstream) party with more power in parliament (Van der Brug et al. 2000). In a context where populist parties have already obtained substantial representation, strategic considerations may be less relevant. This leads us to expect that populist voters will be less likely to switch when populist parties are more prominently established political actors. ${ }^{7}$

Nevertheless, it is uncertain whether this expection holds over the full range of populist parties, with different levels of representation. When a populist party's representation in parliament becomes so substantial that it reaches 'coalition potential' (Sartori 1976: 122), the party may no longer be able to increase its support base. In some cases, populist parties are forced to stay in permanent opposition (cordon sanitaire), which might lead their supporters to consider a stable vote irrelevant in the long run (Pauwels 2011). In addition, government participation by populist parties comes with electoral risks as well. Entering government means losing the 'purity' of their message, making compromises on their policy positions and cooperating with the political establishment (Heinisch 2003; Van Spanje 2011). This leads us to expect that the supposed stabilizing effect of populist parties' representation in parliament on the populist vote lessens (or even reverses) when populist party representation gets really substantial.

Hypothesis 3: The more strongly a populist party is represented in parliament, the more stable will the populist electorate be (with this effect flattening out for the cases with the highest levels of populist party representation).

\section{Data, cases and selection of populist parties}

\section{Assessing voting patterns and sample of elections}

To test our hypotheses, we analyse individual-level voting patterns in parliamentary elections in a broad selection of 14 Western democracies in which it was 
possible to provide a stable vote for a populist party using data from the second, third and fourth modules of the CSES $(2007,2013,2017) .^{8}$ The CSES data are unique for their coverage of a large set of democracies while ensuring crossnational validity by means of identical question wording and coding schemes (Klingeman 2012).

The CSES data are cross-sectional, but the inclusion of a recall question on vote choice in the previous election allows an investigation of citizens' voting patterns in two consecutive elections. While it should be acknowledged that recalling might lead to an underestimation of volatility (e.g. Beasley and Joslyn 2001; Zaller 1992), previous work has shown that inferences drawn from such data are fairly similar to what holds when relying on panel data (Dassonneville and Hooghe 2017b). Furthermore, when focusing on the populist vote, the tendency to report overly consistent recalled votes may also be counterbalanced by the fact that certain social groups (e.g. women and higher educated) are expected to give socially desirable answers and thus under-report (previous) support for (populist) radical right parties (Arzheimer 2017: 283-285). Nevertheless, we cross-validated the data by comparing the recalled voting behaviour of the samples with actual election results. Only the election samples for which the recalled vote closely matched the election results were retained. ${ }^{9}$ This step led us to drop seven elections, leaving a total of 32 elections in the sample.

Given that we investigate the voting patterns of voters who voted for a mainstream party or a populist party at the previous election, we distinguish three possible voting patterns over the course of two consecutive elections: (1) a stable party vote, (2) switching between parties, and (3) switching from a party vote to abstention. The aggregate voting patterns in our set of 32 elections are listed in the online supplementary information in Appendix 1B. ${ }^{10}$ As we should not confuse the voting patterns of voters eligible to cast a vote at both elections with the voting patterns of voters who first entered the electorate at the current election, we limited the sample to respondents aged 23 and older.

\section{Populist parties}

To answer our research questions, we identified 25 parties from 14 countries as prototypical populist parties following the dichotomous classification of populistand non-populist parties by Stijn Van Kessel (2015: 13): 'Political parties are classified as populist parties if they: (1) portray 'the people' as virtuous and essentially homogeneous; (2) advocate popular sovereignty, as opposed to elitist rule; (3) define themselves against the political establishment, which is alleged to act against the interest of "the people".' In order to decide whether a party satisfies all three conditions, Van Kessel relies on a study of secondary and party literature, and the assistance of country experts. Adopting this threefold criterion ensures that parties which only sporadically adopt a populist rhetoric are not grouped together with the prototypical cases of populism (Van Kessel 2015: 4, 34). ${ }^{11}$

The populist parties in our sample are listed online in Appendix 2 and include right-wing, moderate and left-wing populist parties with different amounts of electoral success. ${ }^{12}$ Only populist parties that won at least one seat in national parliaments in any election between 2001 and 2015 are included. For the elections 
in European countries in our sample we followed Van Kessel's classification of populist parties. ${ }^{13}$ Our election sample also contains six elections from three nonEuropean advanced democracies (Australia, Israel and New Zealand). For these countries, we investigated the presence of populist parties in elections by applying Van Kessel's classification method. We classify the following parties as populist parties: the One Nation Party (Australia), New Zealand First Party (New Zealand) and Yisrael Beitenu, Likud, Shas and Yesh Atid (Israel). We provide further motivations for these choices online in Appendix 2C.

We construct a variable indicating a vote for a populist party at the current elections and a variable indicating a vote for a populist party at the previous election. At the election level, we create a variable indicating the overall seat-share percentage of populist parties in the previous election. Data on populist party seat shares comes from the parliaments and government database (Döring and Manow 2017).

\section{Political dissatisfaction and other individual-level measures}

As a measure of generalized dissatisfaction with politics we use a 'satisfaction with democracy' item. The question wording is: 'On the whole, are you very satisfied, fairly satisfied, not very satisfied or not at all satisfied with the way democracy works in [country]?' Although this item is somewhat contested (e.g. Canache et al. 2001; Schedler and Sarsfield 2007), it is considered to be a fairly good summary indicator of political support (Clarke et al. 1993) that taps into individuals' support for the performance of a democratic regime and its actors in general (Linde and Ekman 2003: 401; Söderlund 2008). Lower levels of satisfaction with democracy have also been linked to the core of the populist message as an expression of political antipathy (Van Hauwaert and Van Kessel 2018; Webb 2013).

We control for different individual-level predictors that have been associated with volatility (Dejaeghere and Dassonneville 2017; Van der Meer et al. 2015), voting for populist parties, and with the quality of the recall vote. We control for voters' level of education (whether or not they have a college degree), political knowledge, age, gender $(0=$ female, $1=$ male $)$, and employment status $(1=$ employed, $2=$ unemployed, $3=$ school $/$ student, $4=$ retired $)$. To verify that our conclusions are not solely driven by voters for right-wing populist parties (the dominant type of populist-party), we also control for voters' placement on the ideological left-right dimension (on a scale where left $=0$ and right $=10$ ).

Party identification is considered to be an important vote choice heuristic (Lachat 2007), and partisans are less likely to switch parties or abstain from voting. Others, however, argue that party identification is not exogenous to vote switching and should be considered as an intervening variable between voter characteristics and vote choice (e.g. Söderlund 2008). We therefore estimate our main models without party ID, but control for the effect of party identification in an additional robustness check.

\section{Party system control variables}

Several party system characteristics have been shown to influence volatility. First, the number of viable party alternatives increases the likelihood of vote switching between parties at elections (Pedersen 1979). A larger number of parties may also 
affect switching from a party vote to abstention. When there are more parties, it is more likely that one previously voted for a rather small party that turned out to be unable to have an impact on public policies (let alone participate in government). This may reduce the likelihood of a prolonged vote for such parties. Voters without other clear alternatives may switch to abstaining instead (Taagepera et al. 2014). We control for the number of viable party alternatives that voters have at each election in our sample using the index of the effective number of parties (ENEP) (Laakso and Taagepera 1979). Because the number of effective parties is related to the electoral system (Neto and Cox 1997), we also control for the level of disproportionality in an electoral system (using Michael Gallagher's least squares indicator). The data for both measures come from Gallagher (2017). Because the ideological distance between parties in a party system has an independent effect on vote switching (e.g. Dejaeghere and Dassonneville 2017: 110), we control for the level of polarization in a party system using Russell Dalton's (2008) polarization index measuring the spread of parties along the left-right scale. Furthermore, we control for the number of days between the previous and the current election as more time between elections leads to more switching (Birch 2003). As compulsory voting obviously affects the probability that voters abstain from voting (Singh 2015), we include a dummy variable for elections with compulsory voting and strict sanctions, and a dummy variable for compulsory voting without strict sanctions (see International IDEA 2017). We control for the GDP growth percentage in the election year because it has been argued that economic decline can animate both the electoral successes of populist parties (Arzheimer 2009) and volatile voting behaviour (Dassonneville and Hooghe 2017a). Finally, we include a linear and quadratic term for the year in which an election took place. This controls for the possibility of simultaneous but unrelated (time) trends between the predictor variables and trends in the outcome options (Fairbrother 2014: 124-125).

\section{Method}

Our data set has a hierarchical structure, with 34,893 respondents nested in 32 elections, and these elections nested in 14 countries. Given the categorical nature of our dependent variable and our interest in explanatory factors at the individual and the election level - with the latter requiring multilevel modelling (Gelman and Hill 2007) - we estimate a series of multinomial multilevel regression models with random intercepts at both the election level and the country level. This type of complex multilevel model can be run via the runmlwin command in Stata (Leckie and Charlton 2013). We obtain starting values for our models using second-order penalized quasi-likelihood estimation, and then estimate our final models using Markov Chain Monte Carlo (MCMC) methods (Leckie and Charlton 2013). Model-fit statistics of models estimated by MCMC approximation can be assessed by looking at the Bayesian Deviance Information Criterion, with a lower value indicating a better model fit (Spiegelhalter et al. 2002).

\section{Results}

We first investigate to what extent voters for populist and mainstream parties are dissatisfied with democracy. The average level of satisfaction with democracy 
among voters for populist parties in the pooled data set is 1.56 (on a $0-3$ scale), which is considerably lower than the mean level of satisfaction among voters for mainstream parties (1.80). This finding, while in line with the existing literature, should be nuanced somewhat. Only $11 \%$ of the voters for populist parties report that they are 'not at all satisfied' with the way democracy works (6\% among voters for mainstream parties), while $30.8 \%$ are 'not very satisfied' (20.8\% among voters for mainstream parties). Dissatisfaction is thus certainly stronger among voters for populist parties, but not as omnipresent as sometimes suggested. Furthermore, a large majority $(75 \%)$ of the actual voters who are 'not at all satisfied' with democracy still vote for mainstream parties.

Turning to the main analysis, we ran a series of models with the outcome options of: (1) stable vote for the same party, (2) switch to another party, or (3) switch to abstaining. We thus investigate the effects of our predictor variables on those three outcome categories. A stable party vote serves as the base outcome in our multinomial models.

First, we estimated an intercept-only model. The variance partition coefficients (VPC) of this model show that $7.7 \%$ of the variance in party switching (compared with stable voting) is at the election and country levels while $18.1 \%$ of the variance in switching to abstention is at the election and country levels. Approximately half of the total variance at the higher levels is between-country variance while the other half is between-election variance, but most variance in different voting patterns is thus at the individual level.

The results of our first substantive models are presented in Table $1 .{ }^{14}$ The first set of estimates assesses the impact of the predictors on the outcome category of 'vote switching' relative to 'stable party voting'. The second set of estimates assesses the impact of the predictors on 'switching to abstention' relative to 'stable party voting'. Model I allows testing our first hypothesis by investigating to what extent voters who previously voted for a populist party are voteswitchers compared with voters who voted for mainstream parties. As the ratio of vote switching among voters for populist parties and voters for mainstream parties may vary from election to election, we include random slopes over the election level for the indicator whether one previously voted mainstream or populist. In line with our first hypothesis, the non-significant coefficient of the 'populist voter previous' (PVP) variable suggests that populist party voters are not more likely to switch their votes to other parties, nor are they more likely to switch to abstention compared with voters who voted for mainstream parties at the previous election. ${ }^{15}$

Interpreting the other variables in the model shows that increasing levels of satisfaction with the way democracy works significantly decrease the probability of both party switching and switching to abstention (relative to a stable party vote). Age negatively influences the probabilities of both types of vote switching. A university degree has a small positive effect on the probability of being a vote switcher relative to a stable voter, while it strongly reduces the relative probability of switching to abstention. Those on the right are a bit less likely to switch their votes to other parties than left-wing voters, while no ideological effects can be observed on the probability of switching to abstention. At the election level, the effective number of parties in a political system has a significant positive effect 
Table 1. Explaining vote switching among Populist Party voters and Mainstream Party voters

\begin{tabular}{|c|c|c|c|c|c|c|}
\hline \multirow{2}{*}{$\begin{array}{l}\text { (Ref. outcome = stable } \\
\text { party vote) } \\
\text { Switch = party switch }\end{array}$} & \multicolumn{2}{|c|}{ Model I } & \multicolumn{2}{|c|}{ Model II } & \multicolumn{2}{|c|}{ Model III } \\
\hline & Switch & Abstention & Switch & Abstention & Switch & Abstention \\
\hline \multicolumn{7}{|l|}{ Individual level } \\
\hline Intercept & $\begin{array}{c}-1.573 \\
(1.191)\end{array}$ & $\begin{array}{l}-2.996^{\star \star} \\
(1.229)\end{array}$ & $\begin{array}{c}-1.396 \\
(1.260)\end{array}$ & $\begin{array}{c}-3.524^{\star \star \star} \\
(1.357)\end{array}$ & $\begin{array}{c}-1.934 \\
(1.354)\end{array}$ & $\begin{array}{r}-2.700 \\
(1.653)\end{array}$ \\
\hline $\operatorname{PVP}(0=$ no, $1=$ yes $)$ & $\begin{array}{c}-0.088 \\
(0.244)\end{array}$ & $\begin{array}{r}-0.457^{\star} \\
(0.245)\end{array}$ & $\begin{array}{c}-0.698^{\star \star \star} \\
(0.260)\end{array}$ & $\begin{array}{c}-1.130^{\star \star \star} \\
(0.333)\end{array}$ & $\begin{array}{c}0.658^{\star} \\
(0.399)\end{array}$ & $\begin{array}{c}-1.024^{\star \star} \\
(0.507)\end{array}$ \\
\hline SWD & $\begin{array}{c}-0.224^{\star \star \star} \\
(0.019)\end{array}$ & $\begin{array}{c}-0.491^{\star \star \star} \\
(0.034)\end{array}$ & $\begin{array}{c}-0.262^{\star \star \star} \\
(0.029)\end{array}$ & $\begin{array}{c}-0.525^{\star \star \star} \\
(0.053)\end{array}$ & $\begin{array}{l}-0.223^{\star \star \star} \\
(0.019)\end{array}$ & $\begin{array}{l}-0.487^{\star * \star} \\
(0.033)\end{array}$ \\
\hline $\mathrm{PVP}{ }^{*} \mathrm{SWD}$ & & & $\begin{array}{l}0.446^{\star \star \star} \\
(0.068)\end{array}$ & $\begin{array}{l}0.384^{\star \star \star} \\
(0.108)\end{array}$ & & \\
\hline Age & $\begin{array}{c}-0.017^{\star \star \star} \\
(0.001)\end{array}$ & $\begin{array}{c}-0.025^{\star \star \star} \\
(0.002)\end{array}$ & $\begin{array}{l}-0.017^{\star \star *} \\
(0.001)\end{array}$ & $\begin{array}{c}-0.026^{\star \star \star} \\
(0.002)\end{array}$ & $\begin{array}{l}-0.017^{\star \star \star *} \\
(0.001)\end{array}$ & $\begin{array}{l}-0.026^{\star \star \star} \\
(0.001)\end{array}$ \\
\hline Gender $(0=$ female $)$ & $\begin{array}{c}-0.011 \\
(0.024)\end{array}$ & $\begin{array}{l}-0.148^{\star \star \star} \\
(0.045)\end{array}$ & $\begin{array}{r}-0.013 \\
(0.024)\end{array}$ & $\begin{array}{c}-0.152^{\star \star \star} \\
(0.046)\end{array}$ & $\begin{array}{r}-0.008 \\
(0.025)\end{array}$ & $\begin{array}{c}-0.146^{\star \star \star} \\
(0.045)\end{array}$ \\
\hline University degree ( $0=$ other) & $\begin{array}{l}0.081^{\star \star \star} \\
(0.029)\end{array}$ & $\begin{array}{c}-0.653^{\star \star \star} \\
(0.060)\end{array}$ & $\begin{array}{l}0.082^{\star \star \star} \\
(0.027)\end{array}$ & $\begin{array}{l}-0.646^{\star \star \star} \\
(0.060)\end{array}$ & $\begin{array}{l}0.078^{\star \star \star} \\
(0.029)\end{array}$ & $\begin{array}{c}-0.656^{\star \star \star} \\
(0.063)\end{array}$ \\
\hline Left-right placement $(0-10)$ & $\begin{array}{c}-0.022^{\star \star \star} \\
(0.006)\end{array}$ & $\begin{array}{c}0.014 \\
(0.010)\end{array}$ & $\begin{array}{c}-0.022^{\star \star \star} \\
(0.006)\end{array}$ & $\begin{array}{c}0.013 \\
(0.010)\end{array}$ & $\begin{array}{c}-0.021^{\star \star \star} \\
(0.006)\end{array}$ & $\begin{array}{c}0.015 \\
(0.010)\end{array}$ \\
\hline \multicolumn{7}{|l|}{ Election level } \\
\hline Gallagher Lsq & $\begin{array}{c}0.021 \\
(0.070)\end{array}$ & $\begin{array}{c}0.076 \\
(0.079)\end{array}$ & $\begin{array}{c}0.033 \\
(0.050)\end{array}$ & $\begin{array}{c}0.077 \\
(0.086)\end{array}$ & $\begin{array}{c}0.011 \\
(0.070)\end{array}$ & $\begin{array}{c}0.110 \\
(0.081)\end{array}$ \\
\hline ENEP & $\begin{array}{c}0.196 \\
(0.139)\end{array}$ & $\begin{array}{l}0.318^{\star \star} \\
(0.150)\end{array}$ & $\begin{array}{c}0.123 \\
(0.121)\end{array}$ & $\begin{array}{l}0.327^{\star \star} \\
(0.144)\end{array}$ & $\begin{array}{c}0.218 \\
(0.140)\end{array}$ & $\begin{array}{c}0.182 \\
(0.171)\end{array}$ \\
\hline Polarization & $\begin{array}{c}-0.012 \\
(0.201)\end{array}$ & $\begin{array}{r}-0.078 \\
(0.194)\end{array}$ & $\begin{array}{c}0.029 \\
(0.172)\end{array}$ & $\begin{array}{c}0.003 \\
(0.268)\end{array}$ & $\begin{array}{r}-0.055 \\
(0.210)\end{array}$ & $\begin{array}{c}0.002 \\
(0.262)\end{array}$ \\
\hline Days between elections & $\begin{array}{c}0.001 \\
(0.001)\end{array}$ & $\begin{array}{c}0.001 \\
(0.001)\end{array}$ & $\begin{array}{c}0.001 \\
(0.001)\end{array}$ & $\begin{array}{c}0.001 \\
(0.001)\end{array}$ & $\begin{array}{c}0.001^{\star} \\
(0.001)\end{array}$ & $\begin{array}{c}0.001 \\
(0.001)\end{array}$ \\
\hline \multirow[t]{2}{*}{$\begin{array}{l}\text { - Compulsory voting not } \\
\text { enforced }\end{array}$} & 0.605 & $1.421^{\star}$ & 0.577 & 1.504 & 1.131 & 0.835 \\
\hline & $(0.748)$ & $(0.808)$ & $(0.785)$ & $(0.952)$ & $(0.792)$ & $(0.966)$ \\
\hline - Compulsory voting enforced & $\begin{array}{r}-0.209 \\
(0.406)\end{array}$ & $\begin{array}{c}-1.497^{\star \star} \\
(0.627)\end{array}$ & $\begin{array}{r}-0.387 \\
(0.450)\end{array}$ & $\begin{array}{l}-1.598^{\star \star} \\
(0.683)\end{array}$ & $\begin{array}{c}0.178 \\
(0.354)\end{array}$ & $\begin{array}{l}-1.663^{\star \star} \\
(0.657)\end{array}$ \\
\hline GDP growth \% & $\begin{array}{c}0.046 \\
(0.030)\end{array}$ & $\begin{array}{c}0.057 \\
(0.039)\end{array}$ & $\begin{array}{c}0.046 \\
(0.051)\end{array}$ & $\begin{array}{c}0.019 \\
(0.054)\end{array}$ & $\begin{array}{c}0.052 \\
(0.045)\end{array}$ & $\begin{array}{c}0.052 \\
(0.048)\end{array}$ \\
\hline Election year & $\begin{array}{c}0.075 \\
(0.070)\end{array}$ & $\begin{array}{r}-0.019 \\
(0.099)\end{array}$ & $\begin{array}{c}0.083 \\
(0.071)\end{array}$ & $\begin{array}{r}-0.054 \\
(0.138)\end{array}$ & $\begin{array}{c}0.038 \\
(0.082)\end{array}$ & $\begin{array}{c}0.023 \\
(0.088)\end{array}$ \\
\hline Election year squared & $\begin{array}{c}-0.004 \\
(0.005)\end{array}$ & $\begin{array}{r}-0.000 \\
(0.006)\end{array}$ & $\begin{array}{r}-0.004 \\
(0.004)\end{array}$ & $\begin{array}{c}0.001 \\
(0.008)\end{array}$ & $\begin{array}{r}-0.001 \\
(0.005)\end{array}$ & $\begin{array}{r}-0.004 \\
(0.006)\end{array}$ \\
\hline Seat share populists previous & & & & & $\begin{array}{r}-0.008 \\
(0.033)\end{array}$ & $\begin{array}{c}0.019 \\
(0.039)\end{array}$ \\
\hline \multicolumn{7}{|l|}{ Cross-level interactions } \\
\hline$P V P * S S P P$ & & & & & $\begin{array}{r}-0.073 \\
(0.058)\end{array}$ & $\begin{array}{l}0.162^{\star \star} \\
(0.067)\end{array}$ \\
\hline SSPP*SSPP & & & & & $\begin{array}{c}0.000 \\
(0.001)\end{array}$ & $\begin{array}{c}0.000 \\
(0.001)\end{array}$ \\
\hline$P V P^{\star} S S P P * S S P P$ & & & & & $\begin{array}{c}0.001 \\
(0.001)\end{array}$ & $\begin{array}{l}-0.006^{\star \star \star} \\
(0.002)\end{array}$ \\
\hline Variance (country level) & $\begin{array}{c}0.097 \\
(0.099)\end{array}$ & $\begin{array}{c}0.119 \\
(0.135)\end{array}$ & $\begin{array}{c}0.041 \\
(0.054)\end{array}$ & $\begin{array}{c}0.134 \\
(0.193)\end{array}$ & $\begin{array}{c}0.127 \\
(0.128)\end{array}$ & $\begin{array}{c}0.070 \\
(0.111)\end{array}$ \\
\hline Variance (election level) & $\begin{array}{l}0.159^{* *} \\
(0.071)\end{array}$ & $\begin{array}{c}0.318^{\star \star} \\
(0.140)\end{array}$ & $\begin{array}{l}0.234^{\star \star} \\
(0.105)\end{array}$ & $\begin{array}{l}0.336^{\star \star} \\
(0.161)\end{array}$ & $\begin{array}{l}0.180^{\star \star} \\
(0.080)\end{array}$ & $\begin{array}{l}0.306^{\star \star} \\
(0.120)\end{array}$ \\
\hline Variance (PVP) & $\begin{array}{l}1.380^{\star \star \star} \\
(0.471)\end{array}$ & $\begin{array}{l}1.502^{\star \star} \\
(0.737)\end{array}$ & $\begin{array}{l}1.478^{\star \star *} \\
(0.525)\end{array}$ & $\begin{array}{l}1.572^{\star \star} \\
(0.772)\end{array}$ & $\begin{array}{l}1.084^{\star \star \star} \\
(0.400)\end{array}$ & $\begin{array}{c}0.765 \\
(0.487)\end{array}$ \\
\hline Variance (SWD) & & & $\begin{array}{l}0.013^{*} \\
(0.007)\end{array}$ & $\begin{array}{l}0.038^{\star \star} \\
(0.019)\end{array}$ & & \\
\hline
\end{tabular}


Table 1. Continued

\begin{tabular}{|c|c|c|c|c|c|c|}
\hline \multirow{2}{*}{$\begin{array}{l}\text { (Ref. outcome = stable } \\
\text { party vote) } \\
\text { Switch = party switch }\end{array}$} & \multicolumn{2}{|c|}{ Model I } & \multicolumn{2}{|c|}{ Model II } & \multicolumn{2}{|c|}{ Model III } \\
\hline & Switch & Abstention & Switch & Abstention & Switch & Abstention \\
\hline Observations & \multicolumn{2}{|c|}{34893} & \multicolumn{2}{|c|}{34893} & \multicolumn{2}{|c|}{34893} \\
\hline Elections & \multicolumn{2}{|r|}{32} & \multicolumn{2}{|c|}{32} & \multicolumn{2}{|c|}{32} \\
\hline Countries & \multicolumn{2}{|r|}{14} & \multicolumn{2}{|c|}{14} & \multirow{2}{*}{\multicolumn{2}{|c|}{$\begin{array}{c}14 \\
5383983\end{array}$}} \\
\hline Bayesian DIC & \multicolumn{2}{|c|}{53839.18} & \multicolumn{2}{|c|}{53750.33} & & \\
\hline
\end{tabular}

Notes: Standard deviations in parentheses: ${ }^{\star \star \star} \mathrm{p}<0.01,{ }^{\star \star} \mathrm{p}<0.05,{ }^{\star} \mathrm{p}<0.1$. PVP $=$ populist voter previous; SWD $=$ satisfaction with democracy; SSPP = seat share populists previous; ENEP = effective number of electoral parties (seatshare based).

upon the probability of switching to abstention, while compulsory voting strongly and significantly reduces this probability.

Model II tests our second hypothesis. It allows investigations into how political dissatisfaction among voters for populist parties influences vote switching and whether the impact of dissatisfaction is different among voters for populist parties compared with voters for mainstream parties. For this purpose, an interaction term between the PVP variable and satisfaction with democracy (SWD) is included. In Figure 1, we graphically present the estimated marginal effects of satisfaction with democracy on the two types of vote switching (relative to a stable party vote) ${ }^{16}$ Among voters for mainstream parties there is a significant negative effect of SWD on the relative probabilities of party switching and switching to abstention. Satisfaction with democracy thus stabilizes the vote among voters for mainstream parties. However, among voters for populist parties, there is a significant positive effect by SWD on the relative probability of party switching. Voters for populist parties who are relatively satisfied are thus more likely to switch their vote to another party while political dissatisfaction reduces their probability of party switching relative to a stable vote. The relative predicted probabilities in Figure 2 show that the most dissatisfied voters for populist parties are significantly less likely to switch parties than the most dissatisfied voters for mainstream parties. In contrast, very satisfied voters for populist parties are significantly more likely to be party-switchers than the very satisfied voters for mainstream parties. Those findings are in line with our second hypothesis.

The second set of estimates from model II shows that political dissatisfaction among voters for populist parties has no significant impact on the relative probability of switching to abstention while such a negative effect exists among the voters for mainstream parties. The predicted probabilities of switching to abstention furthermore show that strongly dissatisfied voters for mainstream parties are more than twice as likely to abstain compared to strongly dissatisfied voters for populist parties, this difference is statistically significant at the $p<0.05$ level (Cumming and Finch 2005). The findings from model II are also in line with our expectation (Hypothesis 2 ) that it is political dissatisfaction which primarily binds voters to populist parties and makes them stably vote for them.

To test our expectation that stable party voting among voters who previously voted for a populist party is more likely when a populist party has already succeeded in establishing itself as a considerable force in parliament (Hypothesis 3), 


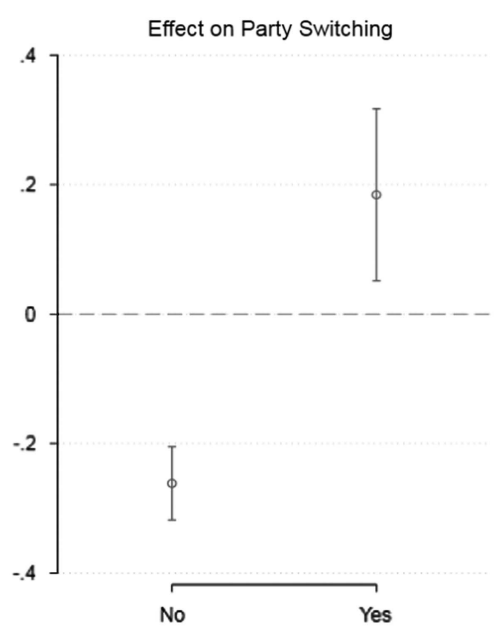

Populist Voter Previous

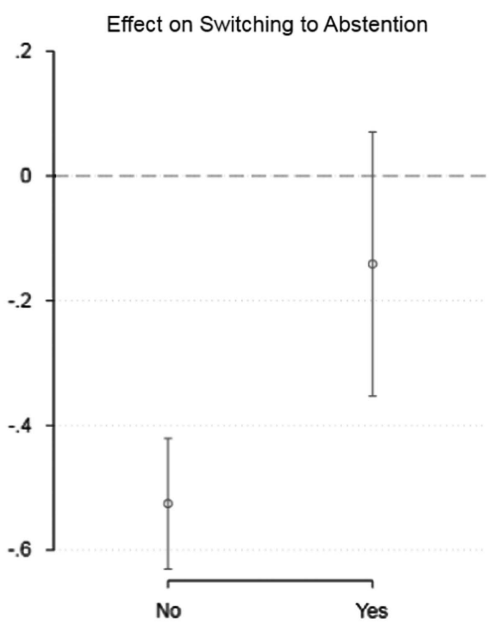

Populist Voter Previous

Figure 1. Relative Marginal Effects of SWD over Populist Voter Previous Election (Model II) Note: The marginal effects are the effects of SWD on the relative probability of choosing party switching over a stable party vote.
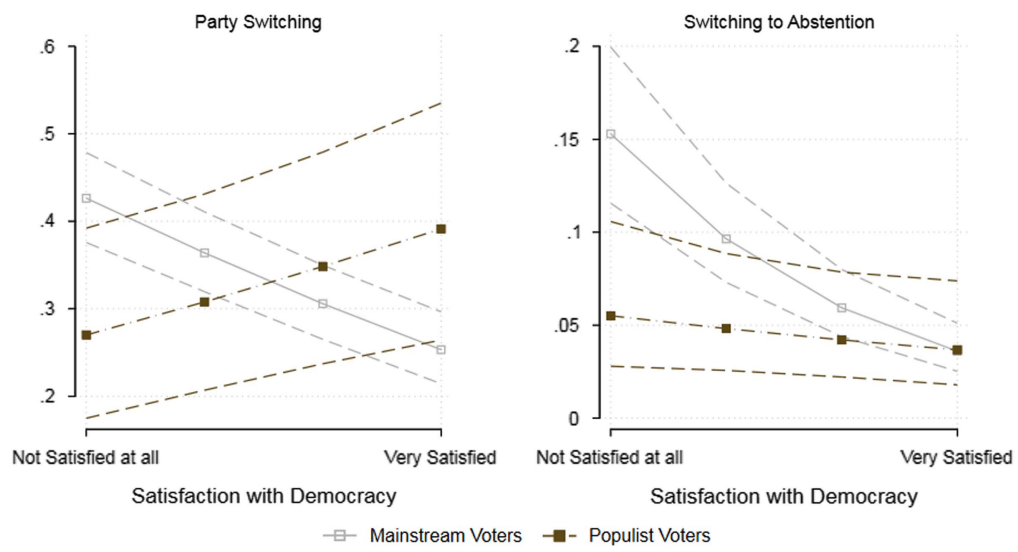

Figure 2. Relative Probabilities of Vote Switching compared with a Stable Party-Vote (Model II)

we included an interaction between PVP and seat-share populist previous (SSPP). Furthermore, as we argued that the effect of SSPP on its capacity to obtain loyal support might follow a curvilinear pattern, those models also contain a quadratic term of SSPP as well as a three-way interaction term of SSPP with PVP. Comparing the model-fit statistics of a model with only the PVP ${ }^{\star}$ SSPP interaction (not shown in the tables) and our model III shows a better model-fit by the latter. The results in model III and the marginal effect plots in Figure 3 show a negative effect of the previous level of populist party representation in parliament upon party switching among voters for populist parties. The average marginal effect is not statistically significant over the whole range of the SSPP variable, but this might be because the 

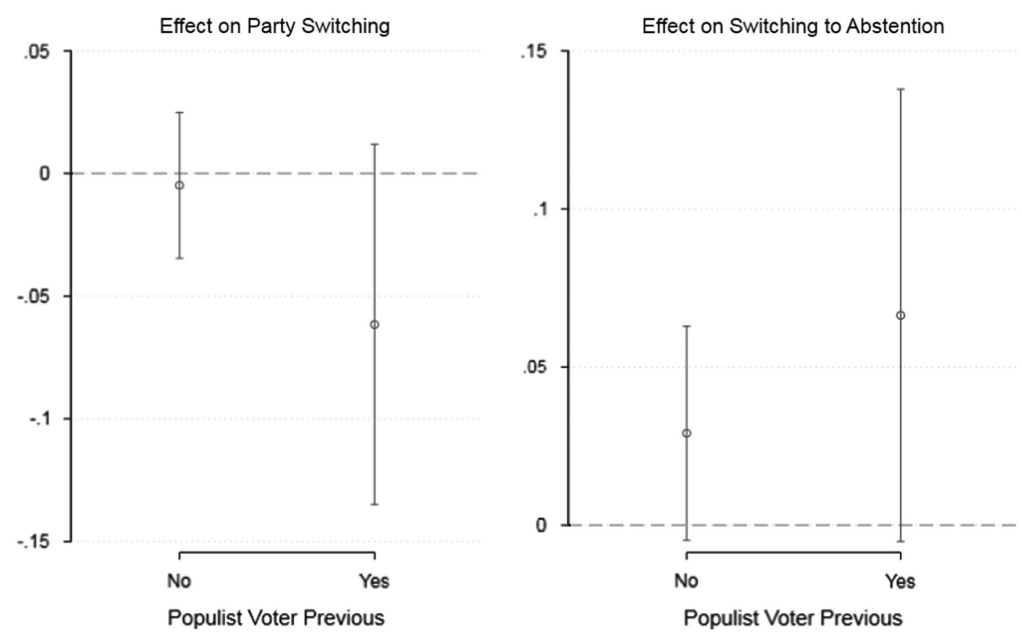

Figure 3. Marginal Effects of Previous Seat Share Populists on Vote Switching (Model III) Note: The marginal effects are the effects of the Previous Seat Share of the Populists on the relative probability of choosing Party Switching over a Stable Party Vote.

effect (as expected) flattens out towards the higher end of the SSPP distribution. ${ }^{17}$ Interpreting the relative predicted probabilities in Figure 4 shows a significant drop in the likelihood of populist party voters switching their votes to another party at the lower ranges of the SSPP variable. The probability of party switching among voters for populist parties starts off relatively high (at almost 0.5 ) when the populist party they voted for is rather small. But when a populist party's previous size increases to a seat share of around $15 \%$, the probability of switching is nearly halved. When a populist party has a seat share of around $20 \%$ and more, its voters become less likely to switch to other parties than the average voters for mainstream parties. At even higher values of SSPP the effect flattens out and becomes insignificant. As our analysis contains only three elections after a government period with a populist party in office, we may have underestimated the curvilinear shape of the effect of populist party size on vote switching among populist party voters. In summary, with regard to party switching, our findings provide good support for our Hypothesis 3. For abstention, however, no clear pattern emerges and voters for populist parties are not very different from voters for mainstream parties.

\section{Robustness tests}

We have verified the robustness of our results when controlling for 'party identification' and 'employment' in the models (models B in the online Appendix). Unsurprisingly, party identification reduces the probabilities of all types of vote switching. Unemployment and being a student increase the probability of party switching, while unemployment and being retired increase the probability of switching to abstention. Adding those control variables does not substantially affect our main findings, though the confidence intervals of the relative predicted probabilities are a bit larger, rendering the predictions of party switching at opposite ends of the SWD variable no longer significantly different when we 

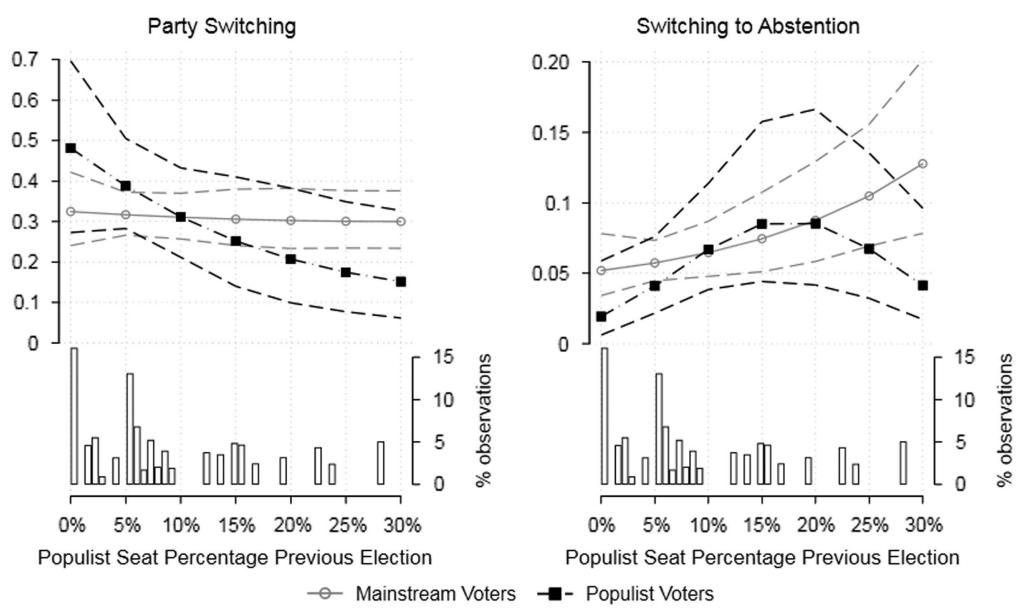

Figure 4. Relative Probabilities of Vote Switching Compared with a Stable Party Vote (Model III)

compare the voters for populist parties with the voters for mainstream parties. The findings regarding the third hypothesis are strengthened after the inclusion of party identification and employment, as the overall marginal effect of the populist seatshare variable becomes significant.

We have also verified whether a stricter exclusion of elections for which vote recall measures might be biased affects our results. Changing the threshold to exclude deviations in the recall vote from 7.5 percentage points to 5 percentage points leads us to drop six additional elections from the sample. Estimating the models on this reduced sample (models $\mathrm{C}$ in the online Appendix) leads to substantially the same results (the findings regarding the third hypothesis are even strengthened).

\section{Discussion}

In this article, we have reassessed the claim that political dissatisfaction is simultaneously related to voting for populist parties and instability in the vote. Using data from the CSES project, we tested three main hypotheses on the stability of voting for populist parties. Our analyses offer evidence that is in line with each of these hypotheses: we find that populist party voters are not more volatile than mainstream voters, that higher levels of political dissatisfaction increase the likelihood of stably voting for a populist party and that stable voting for a populist party is more likely when there is an offer of strong populist parties - though this effect flattens out.

Our findings suggest that in the current era of a 'populist zeitgeist' (Mudde 2004) the populist electorate can no longer be considered a group of volatile voters that come and go. Populist parties attract a core group of voters who are just as loyal to their parties as voters for mainstream parties. This suggests that compared to the past, current-day populist parties may be better at neutralizing dissipating leadership effects and they may be more successful in establishing themselves as political outsiders - despite their more permanent presence in the party system. 
An important key to this success is that populist parties succeed in stably binding a specific part of those voters who are very dissatisfied with politics. Furthermore, it seems that a more permanent presence by strong populist parties in the party system removes some of the initial hesitation that may have existed against (stable) populist party support.

Nevertheless, when investigating the role of dissatisfaction in voting behaviour, we should not focus on populist parties only. A large majority of the politically dissatisfied still vote for mainstream parties or abstain from voting. Carsten Zelle's (1995) logic that 'frustrated voters' are volatile voters still holds among voters for mainstream parties. This reveals that the 'dissatisfied voter' - as an undifferentiated subtype of voters - does not exist. Citizens can be dissatisfied with mainstream politics, while at the same time rejecting populism.

First, not all voters who are dissatisfied with the inefficiency of political institutions and the inherent opportunism in today's political processes may be attracted by the easy solutions that populists propose for such practices. Instead, some 'dissatisfied democrats' might see the populist message - with its glorification of the common people and its usage of simplistic language - as a further example of the opportunistic strategies of political parties. Second, dissatisfied voters (with full populist attitudes) can decide not to support populist parties because of the (extreme) issue positions of populist parties (e.g. Van Hauwaert and Van Kessel 2018). Third, the element of 'people-centrism' in populism (Akkerman et al. 2014; Rooduijn 2018) can scare away voters. Dissatisfied members of minority groups are indeed unlikely to vote for populist parties because these parties often argue that minorities do not belong to 'the pure people'. Finally, the dissatisfied can decide to abstain as well. Roy Kemmers (2017) has argued that this is especially likely for those who think that the political system is not very responsive. In summary, there are good theoretical reasons for explaining why not all dissatisfied mainstream party voters switch to populist party support, and for explaining that party switching and switching to abstention are more common among dissatisfied mainstream party voters. However, with such explanations only recently being developed in the literature, there is plenty of opportunity to improve upon those views and to put them to an empirical test.

Our analyses offer important and new insights into the stability of populist electorates, but we should also acknowledge a number of limitations, which relate mostly to the available data. We do not dispose of panel data for a varied set of democracies and have to rely on the recall questions that are available in the CSES data to model the determinants of vote switching. In addition, we are limited to observing the dynamics of voting behaviour in two consecutive elections. As scholars have shown that distrust is not only the cause of populist voting, but also one of its consequences (Van der Brug 2003; Rooduijn et al. 2016), a potential mechanism for the correlation between dissatisfaction and stable support for a populist party - which we cannot test - is that populist party support further fuels political discontent. We leave it to future research, perhaps on a more limited number of countries, to explore this.

Despite these limitations, our results offer important insights with implications for the debate on the impact of populism on democracy. Presuming that populism has some features that strengthen as well as others that weaken aspects of 
democracy (Mudde and Rovira Kaltwasser 2012), our study shows that one of the supposed positive aspects of populism - that populist parties succeed in stably channelling discontent - functions increasingly well in many Western democracies. This channelling of discontent in a rational, regulated fashion might lead to a sense of democratic fulfilment among populist party voters. Whether this is desirable, however, also depends on the question to what extent political systems with an increasing supply of populist parties succeed in counterbalancing the imminent anti-institutional and often exclusionary tensions inherent in populism (e.g. Kemmers 2017; Rovira Kaltwasser 2012).

Supplementary material. To view supplementary material for this article, please visit https://doi.org/ 10.1017/gov.2018.24

Acknowledgements. An earlier version of this paper was presented at the 2017 ECPR general conference. We thank the discussants and panel participants for their feedback. We would also like to thank Tom van der Meer and the anonymous reviewers for their constructive comments on earlier versions of the manuscript. Remko Voogd gratefully acknowledges financial support from the Netherlands Organization for Scientific Research for his entire PhD project (grant number 407-13-029). Ruth Dassonneville acknowledges support from the Fonds de Recherche du Québec-Société et Culture (grant number 2017NP-199028).

\section{Notes}

1 We limit our empirical investigations to established democracies because the dynamics between political dissatisfaction, vote stability and populist support are substantially different in newer democracies. The political systems of Central and Eastern European countries, for example, are still characterized by a lack of continuity in the party system, higher levels of public dissatisfaction with politics, and with several parties going through episodes of populism long before the rise of populism in the West (Hartleb 2015; Van Kessel 2015; Mudde 2007).

2 Recent studies show that while overwhelming support for the democratic political system itself remained largely unaltered in established democracies (Norris 2011), pessimism about the functioning of political institutions and distrust of its main actors has deepened over the generations (Dalton and Weldon 2005; Mair 2013). The current 'crisis in political trust' is thus foremost a crisis of citizens being dissatisfied with political authority and the way in which political institutions function. The 'dissatisfied voter' is generally unhappy with the functioning of political institutions and distrusts its main actors. This sense of dissatisfaction may lead to a continual rejection of incumbents and officeholders, regardless of who holds power, and risks undermining the legitimacy of government actions and the willingness to obey legislation (e.g. Dalton 2004: 165-169; Marien and Hooghe 2011; Norris 2011).

3 Voters who primarily vote for populist parties to show discontent with the current political elites are called 'protest voters' in the literature (Bergh 2004; Mayer and Perrineau 1992; Rooduijn 2018; Swyngedouw 2001).

4 As the basic populist message can be combined with different ideologies (Taggart 2000) - which makes it applicable to the radical right, the radical left, and even to more moderate contenders (Rooduijn 2018) protest voting might explain support for right-wing just as well as for left-wing populists (Schumacher and Rooduijn 2013: 125).

5 Issue voters primarily support populist radical right parties because of their attitudes towards immigration (Van der Brug et al. 2000, 2005). Issue voting for populist radical left parties may be driven by attitudes towards welfare redistribution (Rooduijn 2018).

6 Although not exactly the same as political dissatisfaction - the concept of populist attitudes also captures to what extent a respondent considers 'the people' as a monolithic whole that should make all important decisions - overall populist attitudes are closely related to political dissatisfaction. Dissatisfaction (with democracy) is even routinely used as a crude proxy for populism (Van Hauwaert and Van Kessel 2018). 7 Theoretically, we only expect our argument to hold when holding the electoral system constant: that is, within the context of a majoritarian system and within the context of systems based on proportional 
representation. As it is harder for (outsider) populist parties to gain representation in majoritarian systems, the mechanism may not apply when comparing parties from different electoral systems. At the empirical level this reservation will, however, not influence our analyses as the set of elections that we use to test this hypothesis only contains data from countries with electoral systems that are based upon proportional representation.

8 We do not include data from the first module of the CSES because a recall question on the vote in the previous election was not included in this module. Our analyses include data from the following countries: Australia, Belgium, Denmark, Finland, Germany, Greece, Ireland, Israel, the Netherlands, New Zealand, Norway, Sweden, Switzerland, and the UK. Given that Belgium can be considered a country with two separate party systems - the Flemish (Dutch-speaking) and Walloon (French-speaking) - samples for Belgium were considered as different election samples.

9 Only election samples for which no single party's vote share in the sample differed by more than 7.5 points from the official results and for which this bias strongly diverged from the bias in the current CSES survey year (difference of more than 5 points) were retained (see also online Appendix 1A).

10 See Appendix 1C for a description of the coding of party switching in all elections in the sample.

11 The usefulness of a dichotomous 'in-or-out' classification of populist parties is sometimes questioned as it is not always straightforward to determine how much populism a party has to express in order to classify it as a 'genuine' populist party. The approach also does not differentiate between populist parties. Several scholars therefore advocate perceiving populism as a phenomenon that can be present to a lesser or larger extent (see, for example, Deegan-Krause and Haughton 2009; Rooduijn and Pauwels 2011; Rooduijn et al. 2016). But despite the fact that placing a party on a populism scale arguably provides some advantages over the dichotomous approach, such an approach is not yet a feasible option to adopt in a multi-country comparative design as placing parties on a populism scale is very demanding and current empirical examples are limited to a few Western European cases (e.g. Rooduijn et al. 2016). Furthermore, we agree with Van Kessel that rejecting the value of the 'dichotomous' approach is overly drastic. The discriminating power of a dichotomous operationalization of populism is evident from analyses of party manifestos that show that populist parties clearly stand out in terms of their populism compared with mainstream parties (Van Hauwaert and Van Kessel 2018; Van Kessel 2015; Rooduijn et al. 2014).

12 The classification of some parties may be controversial among experts. Parties such as the New Flemish Alliance in Belgium and the Dutch Socialist Party may be considered borderline cases. But while they temporarily used populist rhetoric, they do not do this as consistently and to the same degree as the more unambiguous cases of populism. We also follow Van Kessel in not coding Golden Dawn as a populist party during the 2012 election in Greece as the core characteristics of this party are arguably xenophobia and neo-Nazism and not anti-elitism (Van Kessel 2015: 49).

13 With the exception of the 2015 election in the UK. See online Appendix 2B.

14 The models presented here do not include the control variables 'party identification', 'employment', 'political efficacy' or 'political knowledge' as those variables are systematically missing for a few elections, which would reduce the number of elections in our sample. We later provide robustness models in which we include those variables.

15 An inspection of a plot of the different slopes at different electoral periods shows that there is substantial variation in the extent to which populist party voters are volatile or stable voters at the different elections in the study. This is, however, not strange, since in several elections in our election sample the number of voters for populist parties is rather small compared with the number of voters for mainstream parties.

16 Our estimation of predicted probabilities and marginal effects uses the average marginal effect (AME) method. In this method the marginal effects are first calculated for each individual with their observed levels of covariates. These values are then averaged across all individuals. Under AME, the comparison of effect sizes in (multinomial) logit models across groups within one sample is said to be less affected by bias due to varying unobserved heterogeneity across the compared samples than under other approaches such as margins at the means (MEM) (e.g. Mood 2010).

17 In fact, in all the robustness checks we performed we found that this average marginal effect is just at the 'significant' side of the $\alpha=0.05$ threshold. 


\section{References}

Akkerman A, Mudde C and Zaslove A (2014) How Populist Are the People? Measuring Populist Attitudes in Voters. Comparative Political Studies 47(9), 1324-1353.

Akkerman A, Zaslove A and Spruyt B (2017) 'We the People' or 'We the Peoples'? A Comparison of Support for the Populist Radical Right and Populist Radical Left in the Netherlands. Swiss Political Science Review 23(4), 377-403.

Arzheimer K (2009) Contextual Factors and the Extreme Right Vote in Western Europe, 1980-2002. American Journal of Political Science 53(2), 259-275.

Arzheimer K (2017) Electoral Sociology: Who Votes for the Extreme Right and Why - and When? In Mudde C (ed.), The Populist Radical Right: A Reader. London: Routledge, pp. 277-294.

Bartels LM (2002) Beyond the Running Tally: Partisan Bias in Political Perceptions. Political Behavior 24 (2), 117-150.

Beasley RK and Joslyn MR (2001) Cognitive Dissonance and Post-Decision Attitude Change in Six Presidential Elections. Political Psychology 22(3), 521-540.

Bélanger E and Aarts K (2006) Explaining the Rise of the LPF: Issues, Discontent, and the 2002 Dutch Election. Acta Politica 41(1), 4-20.

Bélanger E and Nadeau R (2005) Political Trust and the Vote in Multiparty Elections: The Canadian Case. European Journal of Political Research 44(1), 121-146.

Bergh J (2004) Protest Voting in Austria, Denmark, and Norway. Scandinavian Political Studies 27(4), 367-389.

Betz HG (1994) Radical Right-Wing Populism in Western Europe. London: Macmillan.

Birch S (2003) Electoral Systems and Political Transformation in Post-Communist Europe. London: Palgrave Macmillan.

Blais A, Aldrich JH, Indridason IH and Levine R (2006) Do Voters Vote for Government Coalitions? Testing Downs' Pessimistic Conclusion. Party Politics 12(6), 691-705.

Bos L and Van der Brug W (2010) Public Images of Leaders of Anti-Immigration Parties: Perceptions of Legitimacy and Effectiveness. Party Politics 16(6), 777-799.

Van der Brug W (2003) How the LPF Fuelled Discontent: Empirical Tests of Explanations of LPF Support. Acta Politica 38, 89-106.

Van der Brug W, Fennema M and Tillie J (2000) Anti-Immigrant Parties in Europe: Ideological or Protest Vote? European Journal of Political Research 37(1), 77-102.

Van der Brug W, Fennema M and Tillie J (2005) Why Some Anti-Immigrant Parties Fail and Others Succeed. Comparative Political Studies 38(5), 537-573.

Canache D, Mondak JJ and Seligson MA (2001) Meaning and Measurement in Cross-National Research on Satisfaction with Democracy. Public Opinion Quarterly 65(4), 506-528.

Chiaramonte A and Emanuele V (2017) Party System Volatility, Regeneration and De-Institutionalization in Western Europe (1945-2015). Party Politics 23(4), 376-388.

Clarke HD, Dutt N and Kornberg A (1993) The Political Economy of Attitudes toward Polity and Society in Western European. Journal of Politics 55(4), 998-1021.

Cumming G and Finch S (2005) Inference by Eye: Confidence Intervals and How to Read Pictures of Data. American Psychologist 60(2), 170-180.

Dalton RJ (2004) Democratic Challenges, Democratic Choices: The Erosion of Political Support in Advanced Industrial Democracies. Oxford: Oxford University Press.

Dalton RJ (2008) The Quantity and the Quality of Party Systems: Party System Polarization, its Measurement, and its Consequences. Comparative Political Studies 41(7), 1-22.

Dalton RJ and Weldon SA (2005) Public Images of Political Parties: A Necessary Evil? West European Politics 28(5), 931-951.

Dassonneville R and Hooghe M (2017a) Economic Indicators and Electoral Volatility: Economic Effects on Electoral Volatility in Western Europe, 1950-2013. Comparative European Politics 15(6), 919-943.

Dassonneville R and Hooghe M (2017b) The Noise of the Vote Recall Question: The Validity of the Vote Recall Question in Panel Studies in Belgium, Germany, and the Netherlands. International Journal of Public Opinion Research 29(2), 316-338.

Deegan-Krause K and Haughton T (2009) Toward a More Useful Conceptualization of Populism: Types and Degrees of Populist Appeals in the Case of Slovakia. Politics and Policy 37(4), 821-841. 
Dejaeghere Y and Dassonneville R (2017) A Comparative Investigation into the Effects of Party-System Variables on Party Switching Using Individual-Level Data. Party Politics 23(2), 110-123.

Döring H and Manow P (2017) Parliaments and Governments Database (ParlGov): Information on Parties, Elections and Cabinets in Modern Democracies. Development Version, http://parlgov.org (accessed 12 January 2017).

Downs A (1972) Up and Down With Ecology: The 'Issue Attention Cycle'. Public Interest 28, 38-50.

Fairbrother M (2014) Two Multilevel Modeling Techniques for Analyzing Comparative Longitudinal Survey Datasets. Political Science Research and Methods 2(1), 119-140.

Gallagher M (2017) Election Indices Dataset, www.tcd.ie/Political_Science/staff/michael_gallagher/ ElSystems/index.php (accessed 24 July 2017).

Gelman A and Hill J (2007) Data Analysis Using Regression and Multilevel/Hierarchical Models. Cambridge: Cambridge University Press.

Hartleb F (2015) Here to Stay: Anti-Establishment Parties in Europe. European View 14(1), 39-49.

Van Hauwaert SM and Van Kessel S (2018) Beyond Protest and Discontent: A Cross-National Analysis of the Effect of Populist Attitudes and Issue Positions on Populist Party Support. European Journal of Political Research 57(1), 68-92.

Heinisch R (2003) Success in Opposition - Failure in Government: Explaining the Performance of RightWing Populist Parties in Public Office. West European Politics 26(3), 91-130.

Hooghe L and Marks G (2018) Cleavage Theory Meets Europe's Crises: Lipset, Rokkan, and the Transnational Cleavage. Journal of European Public Policy 25(1), 109-135.

International IDEA (International Institute for Democracy and Electoral Assistance) (2017) Data and Tools, www.idea.int/data-tools (accessed 15 June 2017).

Kemmers R (2017) Channelling Discontent? Non-Voters, Populist Party Voters, and their Meaningful Political Agency. European Journal of Cultural and Political Sociology 4(4), 381-406.

Van Kessel S (2015) Populist Parties in Europe: Agents of Discontent? London: Palgrave Macmillan.

Klingeman HD (ed.) (2012) The Comparative Study of Electoral Systems. Oxford: Oxford University Press.

Kriesi H, Grande E, Lachat R, Dolezal M, Bornschier S and Frey T (2006) Globalization and the Transformation of the National Political Space: Six European Countries Compared. European Journal of Political Research 45(6), 921-956.

Kriesi H, Grande E, Lachat R, Dolezal M, Bornschier S and Frey T (2008) West European Politics in the Age of Globalization. Cambridge: Cambridge University Press.

Laakso M and Taagepera R (1979) 'Effective' Number of Parties: A Measure with Application to West Europe. Comparative Political Studies 12(1), 3-27.

Lachat R (2007) A Heterogeneous Electorate: Political Sophistication, Predisposition Strength and the Voting Decision Process. Baden-Baden: Nomos.

Leckie G and Charlton C (2013) runmlwin: A Program to Run the MLwiN Multilevel Modeling Software from within Stata. Journal of Statistical Software 52(11), 1-40.

Linde J and Ekman J (2003) Satisfaction with Democracy: A Note on a Frequently Used Indicator in Comparative Politics. European Journal of Political Research 42(3), 391-408.

Lubbers $\mathbf{M}$ and Scheepers P (2000) Individual and Contextual Characteristics of the German Extreme Right-Wing Vote in the 1990s: A Test of Complementary Theories. European Journal of Political Research 38(1), 63-94.

Lubbers M, Gijsberts M and Scheepers P (2002) Extreme Right-Wing Voting in Western Europe. European Journal of Political Research 41(3), 345-378.

Mair P (2013) Ruling the Void: The Hollowing of Western Democracy. London: Verso.

Marien S and Hooghe M (2011) Does Political Trust Matter? An Empirical Investigation into the Relation Between Political Trust and Support for Law Compliance. European Journal of Political Research 50(2), 267-291.

Mayer N and Perrineau P (1992) Why Do They Vote for Le Pen? European Journal of Political Research 22(1), 123-141.

Van der Meer TWG, van Elsas E, Lubbe R and van der Brug W (2015) Are Volatile Voters Erratic, Whimsical or Seriously Picky? A Panel Study of 58 Waves into the Nature of Electoral Volatility (The Netherlands 2006-2010). Party Politics 21(1), 100-114.

Mood C (2010) Logistic Regression: Why We Cannot Do What We Think We Can Do, and What We Can Do About It. European Sociological Review 26(1), 67-82. 
Mudde C (2004) The Populist Zeitgeist. Government and Opposition: An International Journal of Politics 39(4), 542-563.

Mudde C (2007) Populist Radical Right Parties in Europe. Cambridge: Cambridge University Press.

Mudde C (2013) Three Decades of Populist Radical Right Parties in Western Europe: So What? European Journal of Political Research 52(1), 1-19.

Mudde C and Rovira Kaltwasser C (2012) Populism and (Liberal) Democracy: A Framework for Analysis. In Mudde C and Rovira Kaltwasser C (eds), Populism in Europe and the Americas: Threat or Corrective for Democracy? Cambridge: Cambridge University Press, pp. 1-26.

Nedelcu H (2015) Anti-Establishment Radical Parties in 21st Century Europe. PhD thesis. Carleton University, Ottowa, https://curve.carleton.ca/7dcaba15-39d1-4911-9a17-addec8fd4f9b.

Neto OA and Cox GW (1997) Electoral Institutions, Cleavage Structures, and the Number of Parties. American Journal of Political Science 41(1), 149-174.

Norris P (1999) Critical Citizens: Global Support for Democratic Government: Global Support for Democratic Government. Oxford: Oxford University Press.

Norris P (2005) Radical Right: Voters and Parties in the Electoral Market. New York: Cambridge University Press.

Norris P (2011) Democratic Deficit. Critical Citizens Revisited. Cambridge: Cambridge University Press.

Pauwels T (2011) Explaining the Strange Decline of the Populist Radical Right Vlaams Belang in Belgium: The Impact of Permanent Opposition. Acta Politica 46(1), 60-82.

Pauwels T (2014) Populism in Western Europe: Comparing Belgium, Germany and the Netherlands. London: Routledge.

Pedersen MN (1979) The Dynamics of European Party Systems: Changing Patterns of Electoral Volatility. European Journal of Political Research 7(1), 1-26.

Poznyak D, Abts K and Swyngedouw M (2011) The Dynamics of the Extreme Right Support: A Growth Curve Model of the Populist Vote in Flanders-Belgium in 1987-2007. Electoral Studies 30(4), 672-688.

Rooduijn M (2018) What Unites the Voter Bases of Populist Parties? Comparing the Electorates of 15 Populist Parties in Western Europe. European Political Science Review 10(3): 351-368.

Rooduijn M and Pauwels T (2011) Measuring Populism: Comparing Two Methods of Content Analysis. West European Politics 34(6), 1272-1283.

Rooduijn M, de Lange SL and Van der Brug W (2014) A Populist Zeitgeist? Programmatic Contagion by Populist Parties in Western Europe. Party Politics 20(4), 563-575.

Rooduijn M, Van der Brug W and de Lange SL (2016) Expressing or Fuelling Discontent? The Relationship Between Populist Voting and Political Discontent. Electoral Studies 43, 32-40.

Rosema M (2006) Partisanship, Candidate Evaluations, and Prospective Voting. Electoral Studies 25(3), 467-488.

Rovira Kaltwasser C (2012) The Ambivalence of Populism: Threat and Corrective for Democracy. Democratization 19(2), 184-208.

Sartori G (1976) Parties and Party Systems: A Framework for Analyses. New York: Cambridge University Press.

Schedler A and Sarsfield R (2007) Democrats with Adjectives: Linking Direct and Indirect Measures of Democratic Support. European Journal of Political Research 46(5), 637-659.

Schumacher G and Rooduijn M (2013) Sympathy for the 'Devil'? Voting for Populists in the 2006 and 2010 Dutch General Elections. Electoral Studies 32(1), 124-133.

Singh SP (2015) Compulsory Voting and the Turnout Decision Calculus. Political Studies 63(3), 548-568.

Söderlund P (2008) Retrospective Voting and Electoral Volatility: A Nordic Perspective. Scandinavian Political Studies 31(2), 217-240.

Van Spanje J (2011) Keeping the Rascals In: Anti-Political-Establishment Parties and their Cost of Governing in Established Democracies. European Journal of Political Research 50(5), 609-635.

Spiegelhalter DJ, Best NG, Carlin BP and Van der Linde A (2002) Bayesian Measures of Model Complexity and Fit. Journal of the Royal Statistical Society Series B (Statistical Methodology) 64(4), 583-639.

Swyngedouw M (2001) The Subjective Cognitive and Affective Map of Extreme Right Voters: Using OpenEnded Questions in Exit Polls. Electoral Studies 20(2), 217-241. 
Taagepera R, Selb P and Grofman B (2014) How Turnout Depends on the Number of Parties: A Logical Model. Journal of Elections, Public Opinion and Parties 24(4), 393-413.

Taggart P (2000) Populism: Concepts in the Social Sciences. Buckingham: Open University Press.

Vliegenthart R, Boomgaarden HG and Van Spanje J (2012) Anti-Immigrant Party Support and Media Visibility: A Cross-Party, Over-Time Perspective. Journal of Elections, Public Opinion and Parties 22(3), 315-358.

de Vries CE and Hobolt SB (2012) When Dimensions Collide: The Electoral Success of Issue Entrepreneurs. European Union Politics 13(2), 246-268.

Webb P (2013) Who is Willing to Participate? Dissatisfied Democrats, Stealth Democrats and Populists in the United Kingdom. European Journal of Political Research 52(6), 747-772.

Werts H, Scheepers P and Lubbers M (2013) Euro-Scepticism and Radical Right-Wing Voting in Europe, 2002-2008: Social Cleavages, Socio-Political Attitudes and Contextual Characteristics Determining Voting for the Radical Right. European Union Politics 14(2), 183-205.

Zaller J (1992) The Nature and Origins of Mass Opinion. Cambridge: Cambridge University Press.

Zelle C (1995) Social Dealignment Versus Political Frustration: Contrasting Explanations of the Floating Vote in Germany. European Journal of Political Research 27(3), 319-345.

Cite this article: Voogd R, Dassonneville R. 2020. Are the Supporters of Populist Parties Loyal Voters? Dissatisfaction and Stable Voting for Populist Parties. Government and Opposition: An International Journal of Comparative Politics 55: 349-370, doi: 10.1017/gov.2018.24 